UDC 661.634.2.061.5

\author{
Bekhzod Karshiev ${ }^{a}$, Atanazar Seytnazarov ${ }^{a}$, Umarbek Alimov ${ }^{b}$, Shafoat Namazov ${ }^{a}$, Akhmed \\ Reymov ${ }^{c}$, A'zamjon Rasulov $^{a}$
}

\title{
PURIFICATION OF WET PROCESS PHOSPHORIC ACID BY DESULFURIZATION AND AMMONIZATION
}

\author{
a Institute of General and Inorganic Chemistry of Academy of Sciences of the Republic of Uzbekistan, \\ Tashkent, Uzbekistan \\ b Tianjin University of Science and Technology, Tianjin, People's Republic of China \\ c Karakalpak State University, Nukus, Uzbekistan
}

\begin{abstract}
We studied the processes of desulfurization of phosphoric acid obtained by wet process from washed and roasted concentrate and subsequent purification of acid from bivalent and trivalent metals and fluorine via partial ammonization (at $\mathrm{pH}$ of 2 to 4). Purified ammoniated slurry containing $16.96 \% \mathrm{P}_{2} \mathrm{O}_{5}, 8.06 \% \mathrm{~N}, 0.09 \% \mathrm{CaO}, 0.58 \% \mathrm{MgO}, 0.004 \%$ $\mathrm{Fe}_{2} \mathrm{O}_{3}, 0.031 \% \mathrm{Al}_{2} \mathrm{O}_{3}, 0.78 \% \mathrm{SO}_{3}$ and $0.52 \% \mathrm{~F}$ was fabricated by the removal of precipitates at the stages of desulfurization and partial ammonization. The rheological properties of ammoniated slurry with $40 \%$ moisture were studied. When the temperature is increased from 40 to $80^{\circ} \mathrm{C}$, both the density and viscosity decrease from 1.395 to $1.365 \mathrm{~g} \mathrm{~cm}^{-3}$ and from 80.8 to $48.7 \mathrm{cP}$, respectively. Ammoniated suspension with $\mathrm{pH}$ of 5.5 and 8.5 was applied to prepare mono- and diammonium phosphates with the ratio $\mathrm{P}_{2} \mathrm{O}_{5}: \mathrm{N}$ of $52: 14$ and 48:18, respectively. The sludge obtained after desulfurization and ammonization processes can be used as a slow-release fertilizer.
\end{abstract}

Keywords: wet process phosphoric acid, calcium-containing material, desulfurization, ammonization, sludge, mono- and diammonium phosphates, composition.

DOI: $10.32434 / 0321-4095-2021-134-1-24-34$

\section{Introduction}

It is known that salts of phosphoric acid are main sources of phosphoric ions for plant nutrition. Phosphoric acid is produced in two ways: by thermal and wet processes. In the first case, a high-purity acid is produced from elemental phosphorus (thermal phosphoric acid, TPA) [1], which is preferably used in pharmaceuticals food industries. Wet process phosphoric acid (WPA) is usually fabricated by sulfuric acid decomposition of natural phosphates and ores [2]. Moreover, WPA can be prepared using nitric and hydrochloric acids to decompose phosphate ores [3]. Taking into account the existing world production of mineral fertilizers, we can state the complete superiority of the sulfuric acid method over nitric acid [4]. WPA contains up to $8-10 \%$ or more of impurities. Therefore, the acid is used mainly for production of phosphate and complex fertilizers. Despite the high purity of TPA, the process of its fabrication seems to be very energy-intensive and costly. The production of TPA requires the energy consumption that is 13 times higher than in production of WPA, besides it is environmentally dangerous [4].

Hence, the above facts can determine both the scientific and practical interest in the study of the process of WPA preparation. The basic method of production of WPA, both in Uzbekistan and abroad, is dihydrate, rather simple and reliable in operation [5]. The most common technological system in the CIS countries has a design capacity of 110 thousand tons of $\mathrm{P}_{2} \mathrm{O}_{5}$ per year $\left(330-360\right.$ tons day $\left.^{-1}\right)$. It includes a double vessel extractor (two connected upper cross-flow cylindrical reactor) with a total volume of $900 \mathrm{~m}^{3}$, and a flume rotary vacuum filter with active (under vacuum) filtering surface of 80 $\mathrm{m}^{2}$. Phosphogypsum is washed from phosphoric acid by a triple counter flow scheme.

In Uzbekistan, JSC «Ammofos-Maxam» produces wet process phosphoric acid by the sulfuric acid extraction of washed and calcinated concentrate (WCC-26), with the following composition (wt.\%)

(C) Bekhzod Karshiev, Atanazar Seytnazarov, Umarbek Alimov, Shafoat Namazov, Akhmed Reymov, A’zamjon Rasulov, 2021

Bekhzod Karshiev, Atanazar Seytnazarov, Umarbek Alimov, Shafoat Namazov, Akhmed Reymov, A'zamjon Rasulov 
$25.77 \mathrm{P}_{2} \mathrm{O}_{5} ; 52.70 \mathrm{CaO}\left(\mathrm{CaO}: \mathrm{P}_{2} \mathrm{O}_{5}=2.05\right) ; 1.20 \mathrm{MgO}$; $0.63 \mathrm{Fe}_{2} \mathrm{O}_{3} ; 1.15 \mathrm{Al}_{2} \mathrm{O}_{3} ; 2.67 \mathrm{SO}_{3} ; 0.04 \mathrm{Cl} ; 3.60 \mathrm{CO}_{2}$; and 6.88 insoluble residue. The optimal parameters of the WPA fabrication are as follows: the extraction temperature of $85-90^{\circ} \mathrm{C}$, the extraction time of $4-6$ hours, the concentration of sulfuric acid of $92-93 \%$, the rate of sulfuric acid of $105 \%$ in terms of stoichiometry, the ratio of liquid to solid (L:S) of 2.9-3.1; the content of $\mathrm{SO}_{3}$ in the liquid phase of the pulp of $2.5-3.0 \mathrm{~g} 100 \mathrm{~cm}^{-3}$, and the $\mathrm{P}_{2} \mathrm{O}_{5}$ concentration of $19-20 \%$. Meanwhile, the average composition of the produced WPA is as follows (wt.\%): $\mathrm{P}_{2} \mathrm{O}_{5}$ 17.0-21.5; $\mathrm{CaO} 0.4-0.6 ; \mathrm{MgO} 0.8-$ $1.2 ; \mathrm{Fe}_{2} \mathrm{O}_{3} 0.4-0.6 \% ; \mathrm{Al}_{2} \mathrm{O}_{3} 0.02-0.04 \% ; \mathrm{F} 1.0-$ $1.3 \%$; $\mathrm{Cl} 0.01-0.015 \% ; \mathrm{SiO}_{2} 1.5 ; \mathrm{SO}_{3} 1.9-3.5 \%$.

At the present time, JSC «Ammofos-Maxam» operates in the following way. WPA is mainly used to produce concentrated nitrogen-phosphorus fertilizers [6]. Then at JSC «Ammofos-Maxam», there are other products such as suprefos-NS $(8-15 \% \mathrm{~N}$; $20-24 \% \quad \mathrm{P}_{2} \mathrm{O}_{5} ; 20-25 \% \quad \mathrm{SO}_{3}$, obtained by deep ammonization of gypsum slurry), ammonium sulfate phosphate $\left(15-19 \% \mathrm{~N} ; 4-23 \% \mathrm{P}_{2} \mathrm{O}_{5} ; 12-21 \% \mathrm{SO}_{3}\right.$, it is a mixture of phosphoric and sulfuric acids), and feed phosphates ammonium (FPA, $12 \% \mathrm{~N} ; 53-55 \%$ $\mathrm{P}_{2} \mathrm{O}_{5}$, obtained on the basis of purification of ammophos slurry) [6]. In addition, the following products have been prepared under laboratory conditions: phosphoric fertilizer analogously to PSagro fertilizer $\left(3.23 \% \mathrm{~N} ; 25.45 \% \mathrm{P}_{2} \mathrm{O}_{5}\right.$; and $18.55 \%$ $\mathrm{SO}_{3}$ ) [7] and enriched superphosphate (22-23\% $\mathrm{P}_{2} \mathrm{O}_{5}$ ), obtained by treatment of phosphorite powder $\left(17-18 \% \quad \mathrm{P}_{2} \mathrm{O}_{5}\right)$ with phosphoric and sulfuric acid [8].

It should be noted that mono- (MAP) and diammonium phosphate (DAP) are the most valuable for Uzbekistan. They are highly concentrated, 100\% water-soluble fertilizers, which are necessary for growing plants with a short growing season and on poor soils with low sorption capacity.

The production of MAP and DAP is based on WPA from the Khibin apatite concentrate $339.4 \%$ $\mathrm{P}_{2} \mathrm{O}_{5}$, Russia) and similar foreign materials Khurigba 80-82 TPL (Morocco), 84 BPL Nauru (Nauru Island) and BuuKraa 80 TPL (Morocco).

Based on these raw materials, it is possible to prepare any types of phosphoric fertilizers with acceptable technical and economic indicators. WPA derived from phosphate materials with low content of $\mathrm{Mg}, \mathrm{Fe}, \mathrm{A} 1, \mathrm{Ca}$ and other impurities is easy evaporated to reach $40-55 \% \mathrm{P}_{2} \mathrm{O}_{5}$. For example, WPA produced from the Khibin concentrate, before evaporation, contains (\%): $\mathrm{P}_{2} \mathrm{O}_{5} 29-30 ; \mathrm{SO}_{3} 1.8-$ 2.5; F 1.5-1.8; $\mathrm{R}_{2} \mathrm{O}_{3} 1.3-2.0 ; \mathrm{CaO} 0.2-0.4$; and
$\mathrm{MgO}$ is absent. After evaporating, the content is as follows: $\mathrm{P}_{2} \mathrm{O}_{5} 50-54 ; \mathrm{SO}_{3} 3.6-5.0 ; \mathrm{F} 0.5-0.8 ; \mathrm{R}_{2} \mathrm{O}_{3}$ 1.6-1.9; $\mathrm{CaO} 0.2-0.6$; and $\mathrm{MgO}$ is absent.

WPA based on phosphorites of Karatau (Kazakhstan) contains (\%): $\mathrm{P}_{2} \mathrm{O}_{5} 22.0 ; \mathrm{MgO} 3.0$; $\mathrm{SO}_{3}$ 2.5; $\mathrm{F} 1.6 ; \mathrm{R}_{2} \mathrm{O}_{3} 2.2 ; \mathrm{CaO} 0.3 ; \mathrm{Fe}_{2} \mathrm{O}_{3} 1.0$; and $\mathrm{Al}_{2} \mathrm{O}_{3}$ 1.2. However, it cannot be subjected to evaporation due to the high content of magnesium in it.

WPA was made from WCC-26, although lowconcentrated $\left(>20 \% \mathrm{P}_{2} \mathrm{O}_{5}\right)$, but contains only $0.4-$ $0.5 \% \mathrm{MgO}$ and is suitable for concentration by evaporation.

Therefore, ammophos (MAP) from the Khibin apatite concentrate contains not less than $52 \% \mathrm{P}_{2} \mathrm{O}_{5}$ (assimilated), not less than $48 \% \mathrm{P}_{2} \mathrm{O}_{5}$ (water-soluble), and $12 \pm 1 \% \mathrm{~N}$ (prime grade) or $50 \pm 1 \% \quad \mathrm{P}_{2} \mathrm{O}_{5}$ (assimilated), not less than $46 \% \mathrm{P}_{2} \mathrm{O}_{5}$ (water-soluble), and $12 \pm 1 \% \mathrm{~N}$ (medium grade.

Meanwhile, MAP of Karatau phosphorite powder refers to the grade $\mathrm{B}$ and contains (wt.\%): 47-48 $\mathrm{P}_{2} \mathrm{O}_{5}$ (total), 43-46 $\mathrm{P}_{2} \mathrm{O}_{5}$ (assimilated), 37$38 \mathrm{P}_{2} \mathrm{O}_{5}$ (water-soluble), $10-11 \mathrm{~N}$, and 6-7 MgO.

MAP based on the WCC-26 contains (wt.\%): 47-48 $\mathrm{P}_{2} \mathrm{O}_{5}$ (total), 44-46 $\mathrm{P}_{2} \mathrm{O}_{5}$ (assimilated), 37$38 \mathrm{P}_{2} \mathrm{O}_{5}$ (assimilated), $10-11 \mathrm{~N}, 1.0-1.5 \mathrm{MgO}$, and $1.0-1.5 \mathrm{~F}$.

At the same time, Chinese manufacturers produce ammophos with $\mathrm{P}_{2} \mathrm{O}_{5}$ content of $\geq 43 \%$, $(\geq 10 \% \mathrm{~N})$. DAP produced in Canada, the United States and Europe commonly contains $47.1 \% \mathrm{P}_{2} \mathrm{O}_{5}$, and $17.89 \% \mathrm{~N}$ [9].

However, the product based on WCC-26 is completely insoluble in water (the ratio of $\mathrm{P}_{2} \mathrm{O}_{5}$ (water-soluble): $\mathrm{P}_{2} \mathrm{O}_{5}$ (assimilated) is less than $80 \%$ ), which is attributed to the contamination of WPA by various impurities. Naturally, the less the contents of $\mathrm{P}_{2} \mathrm{O}_{5}$ (assimilated), $\mathrm{P}_{2} \mathrm{O}_{5}$ (water-soluble) and $\mathrm{N}$, the lower is its grade, i.e. the lower its cost.

In this regard, it is of practical interest to obtain MAP and DAP, the quality of which corresponds to the world standard. Generally, WPA prepared after filtration and separation of gypsum cake contains many impurities, both anionic (sulfate and fluorinecontaining compounds) and cationic (iron, aluminum and magnesium). In addition, it includes some organic impurities. Therefore, to fabricate MAP and DAP of the best brand, WPA is required to be purified. There is a need for precleaning of WPA from various impurities. There are various methods for cleaning phosphoric acid solutions: the method of evaporation, precipitation with various alkaline reagents, cleaning with organic solvents, ion exchange, sorption cleaning with adsorbents and 
recrystallization [4].

Recently researchers have focused on solvent extraction using various alcohols ketones [10-13]. Kijkowska et al. [10] carried out a study on preliminary purification of phosphoric acid concentrated up to $80 \mathrm{wt} . \%$, obtained from apatite of the Kola deposit. First purification was carried out by precipitation of sulfate using $\mathrm{Ca}\left(\mathrm{H}_{2} \mathrm{PO}_{4}\right)_{2} \cdot \mathrm{H}_{2} \mathrm{O}$, $\mathrm{CaHPO}_{4} \cdot 2 \mathrm{H}_{2} \mathrm{O}$ and $\mathrm{Ca}_{3}\left(\mathrm{PO}_{4}\right)_{2}$ (reactive grade) and technical calcium oxide at a molar ratio $\mathrm{Ca}^{2+}: \mathrm{SO}_{2}{ }^{4-}$ of $0.8-1.5$, temperature of $343-363 \mathrm{~K}$ and deposition time of $1800-7200 \mathrm{~s}$. Then, sorption of volatile components $\left(\mathrm{SiF}_{4}\right.$ and $\left.\mathrm{HF}\right)$ and liquid extraction using 4-methyl-2-pentanone (MIBK) were conducted. It has been found that $\mathrm{CaHPO}_{4} \cdot 2 \mathrm{H}_{2} \mathrm{O}$ is the most effective precipitant. The removal of metals was carried out at room temperature with a weight ratio of phosphoric acid to MIBK of 1:1.22. As a result, purified phosphoric acid was fabricated with a concentration of about 50 wt.\% and 1.5 wt.\% MIBK containing $\mathrm{Fe}$ and $\mathrm{Al}$ at a level of $0.01-$ 0.005 wt. $\%$.

However, this method is multistage and requires a long agitation time for desulfurization and, moreover, the consumption of high-purity reagents is irreversible.

Amin et al. [11] reported the preparation of high-grade phosphoric acid by liquid-liquid extraction using n-butanol, n-hexanol, and n-octanol. The acid was extracted from contaminated $9.2 \mathrm{M} \mathrm{H}_{3} \mathrm{PO}_{4}$ at $25^{\circ} \mathrm{C}$ with aqueous/organic phase ratios of $1: 1,1: 3$ and 1:5 in case of butanol, hexanol and octanol, respectively. The results showed $86 \%, 94 \%$ and $87 \%$ acid extraction in 3 steps using butanol, hexanol and octanol, respectively. The process is multistage and power-consuming, which leads to an increase in the cost of the final product.

Hannachi et al. [12] investigated WPA purification with mixtures of methyl isobutyl ketone (MIBK) and tributyl phosphate (TBP). Solvent mixtures were found which produced the highest purified acid with the highest possible $\mathrm{P}_{2} \mathrm{O}_{5}$ recovery for a typical three-step purification process. The purification process consisted of extraction, washing and desorption operations. $\mathrm{P}_{2} \mathrm{O}_{5}$ recovery increased at higher MIBK content in the solvent, while the impurity content was lower for nearly equal weight fractions of TBP and MIBK in the solvent mixture. The best cleaning performance was obtained for a solvent mixture with an optimal MIBK content of $55 \%$, at which the impurity content was reduced. The $\mathrm{P}_{2} \mathrm{O}_{5}$ yield in the process of WPA purification at optimal conditions was about $43 \%$. The disadvantage of this method is a relatively low degree of $\mathrm{P}_{2} \mathrm{O}_{5}$ recovery.

Earlier [13], we offered the solvent extraction to purify WPA, which can be easily regenerated and used repeatedly. Initially, desulfurization of WPA containing (wt.\%) $16.46 \mathrm{P}_{2} \mathrm{O}_{5}, 0.052 \mathrm{CaO}, 1.11 \mathrm{MgO}$, $2.98 \mathrm{SO}_{3}, 0.28 \mathrm{Fe}_{2} \mathrm{O}_{3}, 0.42 \mathrm{Al}_{2} \mathrm{O}_{3}$ and $0.99 \mathrm{~F}$ was performed by means of calcium carbonate. In that case, WPA desulfurization rate was $85.65 \%$. Afterwards, more deep purification process of the desulfurized WPA was applied with using organic solvents (propanol, isopropanol, isobutanol, ethyl alcohols and acetone). Among these solvents, isopropyl alcohol turned out to be the most effective in terms of removing impurities, but significant loss of phosphorus occurs with it. Acetone can be used as an effective precipitant. After regeneration of the acetone and alcohol by distillation, WPA with concentration more than $45 \% \quad \mathrm{P}_{2} \mathrm{O}_{5}$ was produced.

To increase the content of total and watersoluble phosphorus in ammophos or diammophos of WCC-26, Namazov et al. [14] suggested to remove the solid suspensions, compounds of magnesium and iron-aluminum oxides from the slurry of ammonium phosphate (at $\mathrm{pH} 4.4$ ) by means of separating the liquid and solid phase. The composition of the precipitate was as follows: $42.9 \% \mathrm{P}_{2} \mathrm{O}_{5}$ (total), $8.33 \%$ $\mathrm{N}, \mathrm{P}_{2} \mathrm{O}_{5}$ (assimilated) $: \mathrm{P}_{2} \mathrm{O}_{5}$ (total) $=97 \%$, and $\mathrm{P}_{2} \mathrm{O}_{5}$ (water-soluble) $: \mathrm{P}_{2} \mathrm{O}_{5}$ (total) $=70 \%$. The sediment contained up to $10 \% \mathrm{MgO}$, which makes it possible to offer it as a slow releasing NPMg-fertilizer. Then the liquid was evaporated to reach a moisture content of $40 \%$ and ammonization was carried out to $\mathrm{pH}$ 5.5 and 8.5. This allowed preparing the samples of ammophos $\left(\mathrm{N}: \mathrm{P}_{2} \mathrm{O}_{5}=49: 13\right)$ and diammophos $\left(\mathrm{N}: \mathrm{P}_{2} \mathrm{O}_{5}=46: 19\right)$ with improved quality. However, due to a high content of free sulfuric acid in initial WPA $\left(2.61 \% \mathrm{SO}_{3}\right.$ or $\left.3.20 \% \mathrm{H}_{2} \mathrm{SO}_{4}\right)$, the content of nitrogen in the products was increased as a result of the formation of $\left(\mathrm{NH}_{4}\right)_{2} \mathrm{SO}_{4}$ (at least $10 \%$ ), with a decrease in the total content of $\mathrm{P}_{2} \mathrm{O}_{5}$.

Taking account to the above, the goal of this research was to improve the grade of MAP and DAP based on the purification of WPA from various impurities by desulfurization and ammonization.

\section{Materials and methods}

Industrial method of removing sulfates from WPA implies the treatment with natural calcium containing material or a calcium phosphate mineral. Therefore, at the first stage of the study, we investigated the desulfurization of WPA produced by JSC «Ammofos-Maxam» with the following composition (wt.\%): $\mathrm{P}_{2} \mathrm{O}_{5}$ 16.46; $\mathrm{CaO} 0.052 ; \mathrm{MgO}$ $1.11 ; \mathrm{SO}_{3} 2.98 ; \mathrm{Fe}_{2} \mathrm{O}_{3} 0.28 ; \mathrm{Al}_{2} \mathrm{O}_{3}$ 0.42; and $\mathrm{F} 0.99$. WCC-26, the composition of which is given above,

Bekhzod Karshiev, Atanazar Seytnazarov, Umarbek Alimov, Shafoat Namazov, Akhmed Reymov, A'zamjon Rasulov 
as well as $\mathrm{Ca}(\mathrm{OH})_{2}\left(64.5 \% \mathrm{CaO}\right.$ and $\left.24.98 \% \mathrm{CO}_{2}\right)$ and $\mathrm{CaCO}_{3}\left(55.72 \% \mathrm{CaO}\right.$ and $\left.43.78 \% \mathrm{CO}_{2}\right)$ were used as precipitators of sulfate ions in the initial acid. It should be noted that calcium carbonate is decomposed during the thermal enrichment of phosphorite powder washed from the chlorine, the $\mathrm{CO}_{2}$ is released, but resulting free calcium oxide (up to $20 \%$ ) remains in the WCC 26 , thereby increasing calcium content in this module to $2.05 \%$ (whereas it should be no more than 1.5-1.6\%). All types of raw materials were sieved and had a dispersed composition of $0.25 \mathrm{~mm}$. This particle size is quite acceptable for acid decomposition. In addition, the selected particle size does not cause curtains or buildup in hoppers in industrial environment. In order to determine optimal conditions for purification of WPA from sulfate ions, laboratory experiments were conducted in a wide range of standards precipitators (100-150\% of the stoichiometry for the binding of $\mathrm{H}_{2} \mathrm{SO}_{4}$ to $\mathrm{CaSO}_{4}$ ). To this end, the initial WPA was loaded into a reactor with a screw stirrer and heated in a water thermostat to $80^{\circ} \mathrm{C}$. Then the calculated amount of precipitant was gradually dosed to it at a rate of $1.5-2 \mathrm{~g} / \mathrm{min}$. The stirrer speed was $220-250$ $\mathrm{rpm}$. Afterwards, estimated quantity of precipitator was gradually added into the reactor. The duration of desulfurization was $15 \mathrm{~min}$. After the time, the contents of the reactor were kept for $30 \mathrm{~min}$ at $60-$ $65^{\circ} \mathrm{C}$. Further, the desulfurized WPA was separated from the sediments by filtration using the Buchner funnel and a Bunsen flask at a discharge of $0.65 \mathrm{~mm}$ mercury through one layer of filter paper "white» type, and the precipitate was washed with water and then with acetone. After that, the precipitate was dried at $80^{\circ} \mathrm{C}$.

The degree of desulfurization was calculated according to the following equation:

$$
\omega\left(\mathrm{SO}_{3}\right)=\frac{\mathrm{m}_{\text {prec }}\left(\mathrm{SO}_{3}\right)}{\mathrm{m}_{\mathrm{WPA}}\left(\mathrm{SO}_{3}\right)} \cdot 100 \%
$$

where $\omega\left(\mathrm{SO}_{3}\right)$ is the percentage of $\mathrm{SO}_{3}$ in desulfurized WPA after purification (\%); $\mathrm{m}_{\text {prec }}\left(\mathrm{SO}_{3}\right)$ is the content of $\mathrm{SO}_{3}$ in precipitate $(\mathrm{g})$; and $\mathrm{m}_{\mathrm{WPA}}\left(\mathrm{SO}_{3}\right)$ is the content of $\mathrm{SO}_{3}$ in the original WPA (g).

Next, we performed a thorough cleaning of desulfurized WPA from other impurities by partial neutralization at $\mathrm{pH} 2$ to 4 with gaseous ammonia $\left(100 \% \mathrm{NH}_{3}\right)$ and a subsequent separation of the ammoniated pulp on liquid and solid phase by the above procedure. The solid phase was dried at a temperature not higher than $75^{\circ} \mathrm{C}$. Further, the liquid phase was evaporated at a temperature of $85-95^{\circ} \mathrm{C}$ and atmospheric pressure to residual moisture of $40 \%$. Rheological properties (density and viscosity) of evaporated ammonium suspension (at $\mathrm{pH} 4$ ) were determined.

The final stage of the study was ammonization of evaporated ammophos suspension to reach $\mathrm{pH}$ 5.5 and 8.5 with preparation of the MAP and DAP, respectively. To avoid a loss of ammonia, saturation was carried out at a temperature below $70^{\circ} \mathrm{C}$. The granulation of ammoniated prepared slurries was carried out in the drying process by the method of intense mixing and balling. Drying of diammophos and ammophos was carried out at temperatures above $60^{\circ} \mathrm{C}$ and less than $75^{\circ} \mathrm{C}$, respectively.

The compositions of the samples of the initial, desulfurized and ammoniated WPA, its sediments as well as fertilizers were determined by the method described elsewhere [15]. Contents of $\mathrm{CaO}$ and $\mathrm{MgO}$ were determined by volumetric chelatometric method. $\mathrm{P}_{2} \mathrm{O}_{5}$ was determined by UV-spectrometric method (UV-radiation, $\lambda=440 \mathrm{~nm}$ ) using phosphorvanadium-molybdenum complex. The nitrogen content was determined by Kjeldahl-distillation of ammonia in an alkaline medium with Devard alloy followed by titration. The content of $\mathrm{SO}_{3}{ }^{2-}$ ion was determined by via precipitation in the form of barium sulfate (gravimetric method). The contents of $\mathrm{Al}_{2} \mathrm{O}_{3}$ and $\mathrm{Fe}_{2} \mathrm{O}_{3}$ were analyzed by means of complexometric method, and $\mathrm{K}_{2} \mathrm{O}$ and $\mathrm{Na}_{2} \mathrm{O}$ were determined by gravimetric method with tetraphenylborate. Fluorine was determined by potentiometric method using a fluoride selecting electrode. The density of the evaporated ammophos suspension was evaluated using picnometric measurements with an accuracy of $0.05 \%$, kinematic viscosity was determined by means of a glass capillary viscometer VPJ-2 with an uncertainty of $0.2 \%$.

Measurements of $\mathrm{pH}$ of ammophos pulp and $10 \%$ aqueous suspensions of the samples were carried out using ionometer-130M (Russia) equipped with the electrodes ESL 63-07, EVL-1M3.1 and TKA-7 (an accuracy of $0.05 \mathrm{pH}$ units). The strength of the granules in finished fertilizer with the sizes of granules of $2-3 \mathrm{~mm}$ was determined by using a device MIP10-1 (Russia).

\section{Results and discussion}

Table 1 presents the composition of dried sludge obtained by desulfurization of WPA with WCC-26, $\mathrm{Ca}(\mathrm{OH})_{2}$ and $\mathrm{CaCO}_{3}$. The deposition coefficients of components were calculated from their content in the sediment relative to the content in the acid as a percentage (Table 2). The composition of the samples of the desulfurized WPA is given in Table 3. 
It follows from Table 2 that with increasing norms of $\mathrm{Ca}(\mathrm{OH})_{2}$, the deposition coefficient of $\mathrm{SO}_{3}$ in WPA steadily increases from $75.15 \%$ (at a rate of $100 \%$ ) to $86.74 \%$ (at the rate of $150 \%$ ) and the deposition coefficient of $\mathrm{CaO}$ falls from $79.77 \%$ to $66 \%$, respectively. Therefore, $125 \%$ of stoichiometry can be considered as an optimal norm of $\mathrm{Ca}(\mathrm{OH})_{2}$ for sulfate ion deposition from WPA.

The coefficient of deposition of $\mathrm{SO}_{3}, \mathrm{CaO}$, $\mathrm{MgO}, \mathrm{Fe}_{2} \mathrm{O}_{3}, \mathrm{Al}_{2} \mathrm{O}_{3}$ and $\mathrm{F}$ reaches $83.43 \%, 69.37 \%$, $38.79 \%, 5.06 \%, 6.45 \%$ and $5.48 \%$, respectively. An increase in the norm of the precipitator naturally leads to a significant increase in the deposition coefficient. However, a high rate results in an increase in the content of $\mathrm{CaO}$ in acid up to $1.33 \%$ (Table 3), which requires its decalciumination. The choice of $125 \%$ norm is also due to the fact that the deposition rate of $\mathrm{SO}_{3}$ can be reduced. Thus, depending on the rate of $\mathrm{Ca}(\mathrm{OH})_{2}$, the deposition rates of $\mathrm{MgO}, \mathrm{Fe}_{2} \mathrm{O}_{3}$, $\mathrm{Al}_{2} \mathrm{O}_{3}$ and $\mathrm{F}$ are in the following ranges: $31.26-$ $38.79 \%, 5.06-8.60 \%, 6.45-9.42 \%$ and $1.24-7.38 \%$, respectively (Table 2). The loss of $\mathrm{P}_{2} \mathrm{O}_{5}$ with sediment is $6.64-7.16 \%$. The greater the norm of the precipitant, the higher is the deposition coefficient of fluorine.

The composition of sediment samples is as follows (wt.\%): $\mathrm{P}_{2} \mathrm{O}_{5}$ 15.23-18.95, $\mathrm{CaO} 27.41-28.97$, $\mathrm{MgO} 5.58-6.43, \mathrm{Fe}_{2} \mathrm{O}_{3} 0.21-0.38, \mathrm{Al}_{2} \mathrm{O}_{3} 0.39-0.52$, $\mathrm{SO}_{3}$ 34.67-36.85 and $\mathrm{F}$ 0.20-0.98 (Table 1). They are presented mainly in the form of sulfate dihydrate and calcium phosphate, magnesium phosphate, phosphates of oxides and calcium fluoride. These sediments may be used as a phosphorus fertilizer with slow-releasing action, because the content of phosphorus is equal to that of simple superphosphate. If optimal norm is $125 \%$ and $\mathrm{CaCO}_{3}$ is used, then the deposition rate of $\mathrm{SO}_{3}, \mathrm{P}_{2} \mathrm{O}_{5}, \mathrm{CaO}, \mathrm{MgO}, \mathrm{Fe}_{2} \mathrm{O}_{3}$, $\mathrm{A}_{2} \mathrm{O}_{3}$ and $\mathrm{F}$ reaches $85.65 \%, 10.72 \%, 73.54 \%$, $33.66 \%, 7.77 \%, 9.67 \%$ and $4.27 \%$, respectively.

Therefore, $\mathrm{CaCO}_{3}$ ensures the greatest effect in terms of desulfurization of phosphoric acid.

In the case of use of WCC-26, an increase in the rates of precipitator results in an increase in the ratio of WPA desulfurization. However, the use of WCC-26 does not provide a sufficient level of deposition of $\mathrm{MgO}$ (only from 1.11 to $4.87 \%$ ), which is explained by its presence in WCC-26 (Table 2).

Table 2 shows that with increasing norms of WCC-26 from 100 to $150 \%$, the degree of deposition of $\mathrm{P}_{2} \mathrm{O}_{5}, \mathrm{Al}_{2} \mathrm{O}_{3}$ and $\mathrm{F}$ monotonically increases from $4.63 \%$ to $6.33 \%$, from $7.10 \%$ to $9.96 \%$ and from $2.35 \%$ to $3.21 \%$, respectively, whereas the deposition

Sediments composition obtained by desulfurization of WPA

\begin{tabular}{|c|c|c|c|c|c|c|c|}
\hline \multirow{2}{*}{$\begin{array}{c}\text { Rate of } \\
\text { precipitator, \% }\end{array}$} & \multicolumn{7}{|c|}{ Content in dried mass, wt. $\%$} \\
\hline & $\mathrm{P}_{2} \mathrm{O}_{5}$ & $\mathrm{CaO}$ & $\mathrm{MgO}$ & $\mathrm{Fe}_{2} \mathrm{O}_{3}$ & $\mathrm{Al}_{2} \mathrm{O}_{3}$ & $\mathrm{SO}_{3}$ & $\mathrm{~F}$ \\
\hline \multicolumn{8}{|c|}{ Use of $\mathrm{Ca}(\mathrm{OH})_{2}$} \\
\hline 100 & 18.95 & 27.42 & 5.58 & 0.38 & 0.43 & 36.02 & 0.20 \\
\hline 120 & 18.22 & 28.97 & 5.89 & 0.30 & 0.43 & 36.68 & 0.51 \\
\hline 125 & 16.78 & 27.54 & 6.43 & 0.21 & 0.40 & 36.85 & 0.81 \\
\hline 130 & 16.02 & 27.41 & 6.12 & 0.22 & 0.39 & 36.65 & 0.80 \\
\hline 140 & 15.79 & 27.78 & 5.76 & 0.24 & 0.43 & 35.83 & 0.82 \\
\hline 150 & 15.23 & 28.15 & 5.48 & 0.29 & 0.52 & 34.67 & 0.98 \\
\hline \multicolumn{8}{|c|}{ Use of $\mathrm{CaCO}_{3}$} \\
\hline 100 & 23.89 & 23.87 & 3.52 & 0.31 & 0.60 & 32.21 & 0.17 \\
\hline 120 & 23.78 & 25.32 & 3.92 & 0.30 & 0.54 & 32.12 & 0.23 \\
\hline 125 & 22.12 & 24.51 & 4.69 & 0.27 & 0.50 & 32.01 & 0.53 \\
\hline 130 & 21.87 & 24.35 & 4.75 & 0.26 & 0.48 & 31.58 & 0.62 \\
\hline 140 & 21.01 & 24.67 & 4.80 & 0.24 & 0.44 & 30.76 & 0.65 \\
\hline 150 & 20.67 & 24.69 & 4.83 & 0.22 & 0.42 & 30.01 & 0.71 \\
\hline \multicolumn{8}{|c|}{ Use of WCC-26 } \\
\hline 100 & 14.11 & 31.01 & 0.22 & 0.79 & 0.55 & 40.10 & 0.45 \\
\hline 120 & 14.31 & 31.45 & 0.24 & 0.55 & 0.59 & 37.84 & 0.47 \\
\hline 125 & 14.29 & 31.37 & 0.51 & 0.43 & 0.59 & 38.08 & 0.48 \\
\hline 130 & 14.28 & 31.12 & 0.72 & 0.34 & 0.58 & 38.62 & 0.49 \\
\hline 140 & 14.33 & 31.02 & 0.71 & 0.32 & 0.59 & 37.08 & 0.48 \\
\hline 150 & 15.23 & 30.62 & 0.75 & 0.317 & 0.615 & 36.85 & 0.49 \\
\hline
\end{tabular}

Bekhzod Karshiev, Atanazar Seytnazarov, Umarbek Alimov, Shafoat Namazov, Akhmed Reymov, A'zamjon Rasulov 
Effect of rate of precipitator on deposition coefficient from initial WPA

\begin{tabular}{|c|c|c|c|c|c|c|c|}
\hline \multirow{2}{*}{$\begin{array}{c}\text { Rate of } \\
\text { precipitator, \% }\end{array}$} & \multicolumn{7}{|c|}{ Deposition coefficient, wt.\% } \\
\hline & $\mathrm{P}_{2} \mathrm{O}_{5}$ & $\mathrm{CaO}$ & $\mathrm{MgO}$ & $\mathrm{Fe}_{2} \mathrm{O}_{3}$ & $\mathrm{Al}_{2} \mathrm{O}_{3}$ & $\mathrm{SO}_{3}$ & $\mathrm{~F}$ \\
\hline \multicolumn{8}{|c|}{ Use of $\mathrm{Ca}(\mathrm{OH})_{2}$} \\
\hline 100 & 7.16 & 79.77 & 31.26 & 8.60 & 6.50 & 75.15 & 1.24 \\
\hline 120 & 7.15 & 72.31 & 34.26 & 7.12 & 6.71 & 81.65 & 3.33 \\
\hline 125 & 6.82 & 69.37 & 38.79 & 5.06 & 6.45 & 83.43 & 5.48 \\
\hline 130 & 6.71 & 68.48 & 38.05 & 5.49 & 6.53 & 84.83 & 5.57 \\
\hline 140 & 6.64 & 66.50 & 37.24 & 6.26 & 7.49 & 86.28 & 5.94 \\
\hline 150 & 7.15 & 66.00 & 36.83 & 7.86 & 9.42 & 86.74 & 7.38 \\
\hline \multicolumn{8}{|c|}{ Use of $\mathrm{CaCO}_{3}$} \\
\hline 100 & 10.68 & 82.17 & 23.33 & 8.32 & 10.69 & 79.52 & 1.26 \\
\hline 120 & 11.12 & 76.30 & 27.18 & 8.43 & 10.06 & 82.94 & 1.79 \\
\hline 125 & 10.72 & 73.54 & 33.66 & 7.77 & 9.67 & 85.65 & 4.27 \\
\hline 130 & 10.92 & 72.13 & 35.16 & 7.71 & 9.55 & 87.08 & 5.15 \\
\hline 140 & 10.92 & 71.05 & 36.99 & 7.46 & 9.11 & 88.30 & 5.62 \\
\hline 150 & 11.17 & 69.08 & 38.70 & 7.14 & 9.05 & 89.57 & 6.38 \\
\hline \multicolumn{8}{|c|}{ Use of WCC-26 } \\
\hline 100 & 4.63 & 82.93 & 1.11 & 15.42 & 7.10 & 74.46 & 2.35 \\
\hline 120 & 5.36 & 81.20 & 1.39 & 12.12 & 8.69 & 80.54 & 2.77 \\
\hline 125 & 5.41 & 78.31 & 3.19 & 10.09 & 8.68 & 81.87 & 2.84 \\
\hline 130 & 5.45 & 76.10 & 4.26 & 7.60 & 8.67 & 83.94 & 2.96 \\
\hline 140 & 5.82 & 75.53 & 4.49 & 7.70 & 9.28 & 86.01 & 3.06 \\
\hline 150 & 6.33 & 71.58 & 4.87 & 7.77 & 9.96 & 87.57 & 3.21 \\
\hline
\end{tabular}

Composition of desulfurized WPA

\begin{tabular}{|c|c|c|c|c|c|c|c|}
\hline \multirow{2}{*}{$\begin{array}{c}\text { Rate of } \\
\text { precipitator, } \%\end{array}$} & \multicolumn{7}{|c|}{ Content, wt. $\%$} \\
\hline & $\mathrm{P}_{2} \mathrm{O}_{5}$ & $\mathrm{CaO}$ & $\mathrm{MgO}$ & $\mathrm{Fe}_{2} \mathrm{O}_{3}$ & $\mathrm{Al}_{2} \mathrm{O}_{3}$ & $\mathrm{SO}_{3}$ & $\mathrm{~F}$ \\
\hline \multicolumn{8}{|c|}{ Use of $\mathrm{Ca}(\mathrm{OH})_{2}$} \\
\hline 100 & 18.47 & 0.52 & 0.93 & 0.31 & 0.47 & 0.87 & 1.19 \\
\hline 120 & 18.43 & 0.82 & 0.88 & 0.31 & 0.47 & 0.71 & 1.16 \\
\hline 125 & 18.48 & 0.96 & 0.81 & 0.31 & 0.47 & 0.60 & 1.13 \\
\hline 130 & 18.53 & 1.04 & 0.82 & 0.31 & 0.46 & 0.53 & 1.13 \\
\hline 140 & 18.52 & 1.17 & 0.83 & 0.31 & 0.46 & 0.49 & 1.12 \\
\hline 150 & 18.96 & 1.33 & 0.87 & 0.31 & 0.47 & 0.47 & 1.14 \\
\hline \multicolumn{8}{|c|}{ Use of $\mathrm{CaCO}_{3}$} \\
\hline 100 & 18.21 & 0.47 & 1.06 & 0.32 & 0.46 & 0.76 & 1.22 \\
\hline 120 & 18.19 & 0.74 & 1.01 & 0.32 & 0.47 & 0.62 & 1.21 \\
\hline 125 & 18.42 & 0.87 & 0.93 & 0.32 & 0.47 & 0.53 & 1.20 \\
\hline 130 & 18.23 & 0.94 & 0.90 & 0.32 & 0.46 & 0.47 & 1.19 \\
\hline 140 & 18.20 & 1.06 & 0.88 & 0.32 & 0.46 & 0.43 & 1.18 \\
\hline 150 & 18.16 & 1.21 & 0.87 & 0.32 & 0.47 & 0.41 & 1.17 \\
\hline \multicolumn{8}{|c|}{ Use of WCC-26 } \\
\hline 100 & 18.65 & 0.42 & 1.24 & 0.28 & 0.47 & 0.88 & 1.19 \\
\hline 120 & 19.15 & 0.55 & 1.29 & 0.30 & 0.47 & 0.69 & 1.23 \\
\hline 125 & 19.01 & 0.63 & 1.27 & 0.31 & 0.47 & 0.61 & 1.22 \\
\hline 130 & 18.79 & 0.72 & 1.25 & 0.31 & 0.47 & 0.54 & 1.21 \\
\hline 140 & 18.89 & 0.81 & 1.24 & 0.32 & 0.47 & 0.51 & 1.22 \\
\hline 150 & 18.99 & 0.99 & 1.22 & 0.32 & 0.47 & 0.41 & 1.22 \\
\hline
\end{tabular}


coefficient of $\mathrm{Fe}_{2} \mathrm{O}_{3}$ on the contrary reduces from $15.42 \%$ to $7.77 \%$. Apparently, this is due to an increase in the solubility of $\mathrm{FePO}_{4}$ in WCC-26.

To obtain high-quality ammonium phosphates (MAP and DAP), the acid was partially neutralized with gaseous ammonia from $\mathrm{pH} 2.0$ to $\mathrm{pH} 4.0$ at $80^{\circ} \mathrm{C}$. Then the contents of the reactor were filtered out. The liquid part and the dried sediment from the ammoniated pulp were subjected to chemical analysis. Table 4 presents the composition of precipitates obtained when ammonization of desulfurized WPA. The deposition coefficients of components were calculated from their contents in the sediment relative to the content in the desulfurized acid as a percentage (Table 5). The composition of the desulfurized WPA is given in Table 6.

Since the sediments of ammoniated pulps were not washed with water or organic solvents, it is obvious that nitrogen and water-soluble form of $\mathrm{P}_{2} \mathrm{O}_{5}$ can exist as ammonium sulfate and phosphates (Table 4). The presence of nitrogen can be explained by the presence of complex salts of iron and aluminium. An increase of $\mathrm{N}$ in precipitates with increasing $\mathrm{pH}$ occurs as a result of the crystallization of monoammonium phosphate. Calcium is presented in precipitates as dicalcium phosphate. However, the main result is that $56-80 \%$ of phosphorus is in watersoluble form with respect to its total content in the precipitate. Due to a high concentration of

Sediments composition obtained from desulfurized WPA at various pH

Table 4

Sediments composition obtained from desulfurized WPA at various $\mathrm{pH}$

\begin{tabular}{|c|c|c|c|c|c|c|c|c|c|}
\hline \multirow{2}{*}{ Slurry pH } & \multicolumn{9}{|c|}{ Content, wt. \% } \\
\hline & $\mathrm{P}_{2} \mathrm{O}_{5}$ (total) & $\mathrm{P}_{2} \mathrm{O}_{5}$ (water) & $\mathrm{N}$ & $\mathrm{CaO}$ & $\mathrm{MgO}$ & $\mathrm{Fe}_{2} \mathrm{O}_{3}$ & $\mathrm{Al}_{2} \mathrm{O}_{3}$ & $\mathrm{SO}_{3}$ & $\mathrm{~F}$ \\
\hline 2.01 & 54.45 & 30.48 & 4.98 & 7.56 & 1.03 & 4.25 & 2.54 & 3.69 & 3.82 \\
\hline 2.23 & 53.23 & 31.24 & 5.23 & 5.53 & 1.01 & 5.98 & 5.28 & 2.28 & 4.68 \\
\hline 2.52 & 48.26 & 29.51 & 5.83 & 3.76 & 1.44 & 4.31 & 5.39 & 1.45 & 4.96 \\
\hline 2.85 & 46.56 & 29.78 & 5.91 & 3.42 & 1.54 & 3.72 & 4.74 & 1.18 & 4.93 \\
\hline 3.01 & 45.45 & 30.05 & 6.18 & 3.43 & 1.89 & 3.38 & 4.39 & 1.12 & 5.08 \\
\hline 3.54 & 40.56 & 30.61 & 6.85 & 3.24 & 2.09 & 2.66 & 3.68 & 0.86 & 4.86 \\
\hline 4.01 & 37.63 & 29.94 & 7.18 & 3.88 & 3.27 & 2.38 & 3.37 & 1.11 & 5.87 \\
\hline
\end{tabular}

Table 5

Effect of pH of ammoniated WPA on deposition coefficient of components

\begin{tabular}{c|c|c|c|c|c|c|c}
\hline \multirow{2}{*}{ Slurry pH } & \multicolumn{7}{|c}{ Deposition coefficient, wt.\% } \\
\cline { 2 - 8 } & $\mathrm{P}_{2} \mathrm{O}_{5}$ & $\mathrm{CaO}$ & $\mathrm{MgO}$ & $\mathrm{Fe}_{2} \mathrm{O}_{3}$ & $\mathrm{Al}_{2} \mathrm{O}_{3}$ & $\mathrm{SO}_{3}$ & $\mathrm{~F}$ \\
\hline 2.01 & 3.68 & 16.10 & 1.44 & 16.59 & 6.71 & 6.03 & 3.99 \\
\hline 2.23 & 8.60 & 28.12 & 3.37 & 55.72 & 33.30 & 8.90 & 11.68 \\
\hline 2.52 & 14.79 & 36.27 & 9.12 & 76.17 & 64.47 & 10.73 & 23.49 \\
\hline 2.85 & 20.57 & 47.56 & 14.06 & 94.78 & 81.74 & 12.59 & 33.66 \\
\hline 3.01 & 22.51 & 53.48 & 19.35 & 96.56 & 84.89 & 13.40 & 38.89 \\
\hline 3.54 & 25.67 & 64.55 & 27.34 & 97.09 & 90.92 & 13.15 & 47.53 \\
\hline 4.01 & 27.02 & 87.69 & 48.53 & 98.56 & 94.46 & 19.26 & 65.13 \\
\hline
\end{tabular}

Composition of ammoniated suspension at different $\mathrm{pH}$

\begin{tabular}{c|c|c|c|c|c|c|c|c}
\hline \multirow{2}{*}{ Slurry pH } & \multicolumn{9}{|c}{ Content, wt.\% } \\
\cline { 2 - 9 } & $\mathrm{P}_{2} \mathrm{O}_{5}$ & $\mathrm{~N}$ & $\mathrm{CaO}$ & $\mathrm{MgO}$ & $\mathrm{Fe}_{2} \mathrm{O}_{3}$ & $\mathrm{Al}_{2} \mathrm{O}_{3}$ & $\mathrm{SO}_{3}$ & $\mathrm{~F}$ \\
\hline 2.01 & 17.25 & 5.01 & 0.48 & 0.86 & 0.260 & 0.430 & 0.70 & 1.120 \\
\hline 2.23 & 16.88 & 5.38 & 0.43 & 0.88 & 0.144 & 0.321 & 0.71 & 1.076 \\
\hline 2.52 & 16.84 & 6.46 & 0.40 & 0.87 & 0.081 & 0.180 & 0.73 & 0.981 \\
\hline 2.85 & 16.98 & 7.76 & 0.36 & 0.89 & 0.019 & 0.100 & 0.77 & 0.916 \\
\hline 3.01 & 16.82 & 7.78 & 0.32 & 0.85 & 0.011 & 0.082 & 0.78 & 0.862 \\
\hline 3.54 & 16.69 & 7.92 & 0.25 & 0.79 & 0.010 & 0.052 & 0.81 & 0.764 \\
\hline 4.01 & 16.96 & 8.06 & 0.09 & 0.58 & 0.004 & 0.031 & 0.78 & 0.521 \\
\hline
\end{tabular}

Bekhzod Karshiev, Atanazar Seytnazarov, Umarbek Alimov, Shafoat Namazov, Akhmed Reymov, A'zamjon Rasulov 
phosphorus (37.63-54.45\% $\mathrm{P}_{2} \mathrm{O}_{5}$ (total)) and nitrogen $(4.98-7.18 \% \mathrm{~N})$, the precipitate can serve as an independent fertilizer, ammophos.

According to data of Table 5 and Fig. 1, calcium and iron-aluminum oxides at $\mathrm{pH}$ of about 4.0 are almost completely recovered from ammonium phosphate solutions. In this case, the content of magnesium is reduces almost by half, the contents of sulfate and fluorine ions decrease by $\sim 20 \%$ and $\sim 65 \%$, and the loss of $\mathrm{P}_{2} \mathrm{O}_{5}$ with sediment reaches $27 \%$.

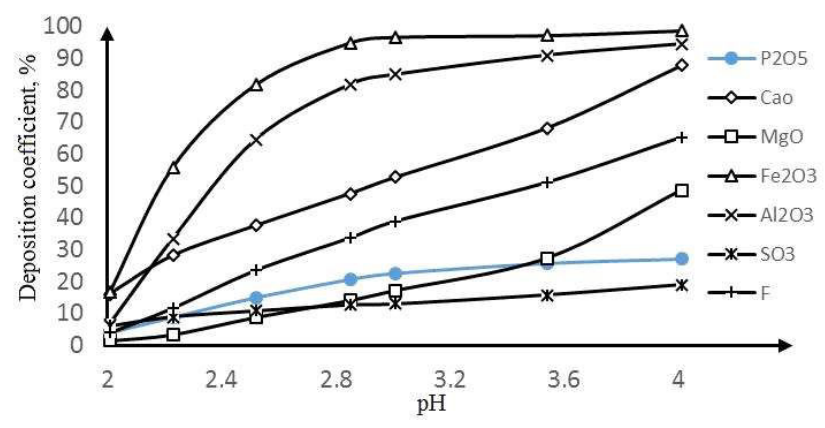

Fig. 1. Deposition coefficient from desulfurized WPA as a function of $\mathrm{pH}$ of ammoniated slurry

Here it is appropriate to give the results of studying the solid phases formed during the ammonization of WPA from Karatau phosphorites, which contains (wt.\%): $\mathrm{P}_{2} \mathrm{O}_{5} 20.3 ; \mathrm{CaO} 0.24, \mathrm{SO}_{3}$ 2.1; $\mathrm{Al}_{2} \mathrm{O}_{3} 1.04 ; \mathrm{Fe}_{2} \mathrm{O}_{3} 1.02 ; \mathrm{MgO} 1.78$, and $\mathrm{F} 2.72$. WPA under consideration is similar to this acid. So, when ammonization of WPA from Karatau phosphorite is performed to reach $\mathrm{pH}$ of about 2.5, the following compounds are formed that are soluble in water: $\mathrm{NH}_{4} \mathrm{H}_{2} \mathrm{PO}_{4}, \mathrm{NH}_{4} \mathrm{HSO}_{4} \cdot \mathrm{NH}_{4} \mathrm{H}_{2} \mathrm{PO}_{4}$, $\left(\mathrm{NH}_{4}\right)_{2} \mathrm{SiF}_{6}$, and citric soluble complex phosphates of iron and aluminium $(\mathrm{Fe}, \mathrm{Al})_{3} \mathrm{NH}_{4} \mathrm{H}_{8}\left(\mathrm{PO}_{4}\right)_{6} \cdot 6 \mathrm{H}_{2} \mathrm{O}$, $(\mathrm{Fe}, \mathrm{Al}) \mathrm{NH}_{4} \mathrm{HPO}_{4} \mathrm{~F}_{2}$ and $\mathrm{Mg}(\mathrm{Fe}, \mathrm{Al}) \mathrm{NH}_{4}\left(\mathrm{HPO}_{4}\right)_{2} \mathrm{~F}_{2}$. The first complex is well crystallized, easily filtered and separated. The second one is amorphous, it forms colloid that is hardly precipitated and poorly filterable. The soluble compound $\mathrm{Mg}(\mathrm{Fe}, \mathrm{Al}) \mathrm{NH}_{4}\left(\mathrm{HPO}_{4}\right)_{2} \mathrm{~F}_{2}$ is formed in magnesium-containing acids and crystallizes well. When ammonization is conducted to reach $\mathrm{pH}$ of about 2.5, almost all iron ions and only a part of aluminum, magnesium and fluorine are released into the precipitate.

In the $\mathrm{pH}$ range of 2.5-5.5, the following compounds are formed: $\mathrm{NH}_{4} \mathrm{H}_{2} \mathrm{PO}_{4} ;\left(\mathrm{NH}_{4}\right)_{2} \mathrm{SO}_{4}$; $\mathrm{MgHPO}_{4} ; \mathrm{Mg}(\mathrm{Fe}, \mathrm{Al}) \quad\left(\mathrm{NH}_{4}\right)_{2}\left(\mathrm{HPO}_{4}\right)_{2} \mathrm{~F}_{3}$; $\mathrm{Mg}_{3}\left(\mathrm{NH}_{4}\right)_{2}\left(\mathrm{HPO}_{4}\right)_{4} \cdot 8 \mathrm{H}_{2} \mathrm{O} ; \mathrm{MgNH}_{4} \mathrm{PO}_{4} \cdot \mathrm{H}_{2} \mathrm{O}$; $\mathrm{MgNH}_{4} \mathrm{HFPO}_{4} ;(\mathrm{Fe}, \mathrm{Al}) \mathrm{NH}_{4}\left(\mathrm{HPO}_{4}\right)_{2} \cdot 0.5 \mathrm{H}_{2} \mathrm{O} ;(\mathrm{Fe}$, $\mathrm{Al}) \mathrm{NH}_{4} \mathrm{HPO}_{4} \mathrm{~F}_{2} ; \mathrm{SiO}_{2} ; \mathrm{CaHPO}_{4}$; and $\mathrm{Ca}_{5}\left(\mathrm{PO}_{4}\right)_{3} \mathrm{OH}$.
All phosphates contained in ammonium phosphate, except hydroxyapatite, are citric-soluble.

Particular attention was paid to the composition of the liquid phase of the ammoniated pulp at $\mathrm{pH}$ 4.01. The composition of this suspension can be seen in Table 6. This purified suspension served as the initial component for the production of high-quality ammonium phosphates (MAP and DAP).

According to the current production technology of ammophos, the ammoniated pulp with a moisture content of about $60 \%$ is evaporated in a surfacetype apparatus with forced circulation to reach a moisture content of $30-35 \%$ and then fed to a pelletizing drum granulator-dryer. At the same time, the pulp should retain fluidity and be easily pumped by pumps.

Therefore, evaporation of the ammoniated suspension was carried out at a temperature of 85$95^{\circ} \mathrm{C}$ at atmospheric pressure to a residual moisture of $40 \%$. The density and viscosity of the evaporated liquid phase of ammophos pulp at $\mathrm{pH} 4.01$ are shown in Fig. 2.

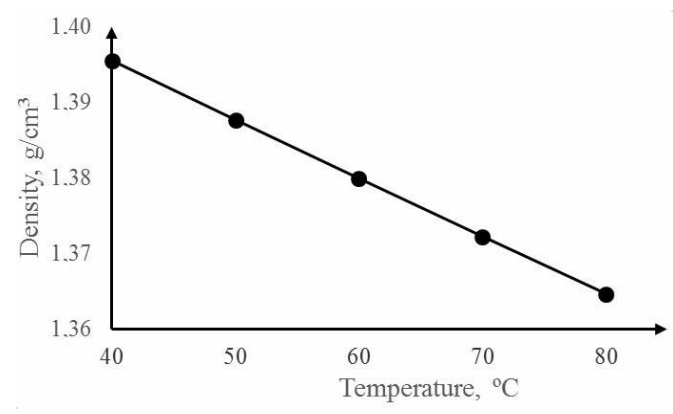

$\mathbf{a}$

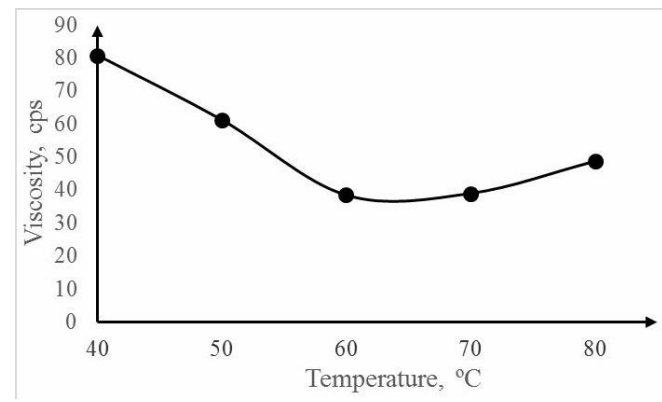

b

Fig. 2. Temperature dependences of density (a) and viscosity (b) of evaporated ammophos suspension

At $40 \%$ humidity, when the temperature rises from 40 to $80^{\circ} \mathrm{C}$, the pulp density decreases from 1.395 to $1.365 \mathrm{~g} / \mathrm{cm}^{3}$, while viscosity decreases from 80.8 to 48.7 centipoise. With increasing temperature, 
the pulp density decreases rectilinearly, but the viscosity steadily increases, which, apparently, can be explained by the transition of complex salts from the crystalline to the gel-like amorphous state.

Thus, under industrial conditions, it is advisable to evaporate the ammophos pulp originated from the WCC-26 to a humidity of $35 \%$. At lower humidity and temperatures $80-90^{\circ} \mathrm{C}$, monoammonium phosphate begins to crystallize and the viscosity of the pulp increases dramatically inducing hardly to pump by pumps.

At the final stage, ammonization of evaporated ammonization of the pulp was performed to reach $\mathrm{pH} 5.5$ and $\mathrm{pH} 8.5$ and produce ammophos and diammophos, respectively. The procedure of preparation of the finished products is described above.

According to the requirement of State standard 18918-85, MAP must contain at least $12 \% \mathrm{~N}$ and $52 \% \mathrm{P}_{2} \mathrm{O}_{5}$ (assimilated), whereas according to the technical conditions 113-08-537-83, DAP should contain $18 \% \mathrm{~N}$ and $48 \% \mathrm{P}_{2} \mathrm{O}_{5}$ (assimilated).

The results show that the granular MAP has the following composition (wt.\%): $\mathrm{P}_{2} \mathrm{O}_{5} 51.6 ; \mathrm{N} \mathrm{14}$; $\mathrm{SO}_{3}$ 0.98; $\mathrm{CaO} 0.5 ; \mathrm{MgO} 1.74 ; \mathrm{Fe}_{2} \mathrm{O}_{3} 0.04 ; \mathrm{Al}_{2} \mathrm{O}_{3}$ 0.14 ; F not more than 1.0; the granule strength being $3.25 \mathrm{MPa}$. Ammophos possessing these characteristics is in great demand. DAP contains $48 \% \mathrm{P}_{2} \mathrm{O}_{5}$ and $18.7 \% \mathrm{~N}$, the hardness of granules being at least 2 $\mathrm{MPa}$. It contains $0.44 \% \mathrm{CaO} ; 1.7 \% \mathrm{MgO} ; 0.04 \%$ $\mathrm{Fe}_{2} \mathrm{O}_{3} ; 0.13 \% \quad \mathrm{Al}_{2} \mathrm{O}_{3} ; 1 \% \mathrm{SO}_{3}$ and not more than $1.0 \% \mathrm{~F}$.

It should be noted that phosphorus in these products is exclusively in water-soluble form. The MAP consists of $\mathrm{NH}_{4} \mathrm{H}_{2} \mathrm{PO}_{4}$ with some $\left(\mathrm{NH}_{4}\right)_{2} \mathrm{HPO}_{4}$. DAP contains $\left(\mathrm{NH}_{4}\right)_{2} \mathrm{HPO}_{4}$ and partially $\left(\mathrm{NH}_{4}\right)_{3} \mathrm{PO}_{4}$.

\section{Conclusions}

To produce concentrated grades of ammonium phosphates that meet the requirements of the world standard towards a phosphorus component, it is necessary to use WPA desulfurized and purified from impurities. It is desirable to use $\mathrm{CaCO}_{3}$ as a precipitator at the rate of $125 \%$ of stoichiometry for desulfurization of WPA of WCC-26, the rate of desulfurization reaches $85.65 \%$. Other impurities $\left(\mathrm{CaO}, \mathrm{MgO}, \mathrm{Fe}_{2} \mathrm{O}_{3}, \mathrm{Al}_{2} \mathrm{O}_{3}\right.$ and $\left.\mathrm{F}\right)$ are further removed with gypsum. Gypsum sediment with a content of $15-19 \% \mathrm{P}_{2} \mathrm{O}_{5}$ can be used as a phosphorus fertilizer of slow-releasing action.

For maximum removal of the above impurities from the composition of desulfurized WPA, the latter was partially ammoniated to reach pH of 2 to 4 .
Almost complete recovery of calcium was observed at $\mathrm{pH}$ about 4.0. The resulting sediments contain from 4.98 to $7.18 \% \mathrm{~N}, 37.63-54.45 \% \mathrm{P}_{2} \mathrm{O}_{5}$ (total); $56-80 \%$ of them being in water-soluble form. Thus, they can be recycled to ammophos production.

Purified suspension of ammonium phosphate ( $\mathrm{pH} 4)$ served as a starting component for highquality phosphate fertilizers. Ammonization of evaporated ammophos pulp to $\mathrm{pH} 5.5$ and 8.5 was the basis for the production of MAP and DAP, respectively. MAP with the ratio $\mathrm{P}_{2} \mathrm{O}_{5}: \mathrm{N}=52: 14$ and DAP with the ratio $\mathrm{P}_{2} \mathrm{O}_{5}: \mathrm{N}=48: 18$ were produced. Phosphorus in these products is exclusively in watersoluble form.

\section{REFERENCES}

1. Babrauskas V. Phosphorus explosions // Process Saf. Environ. Prot. - 2017. - Vol.107. - P.87-93.

2. Behaviour and fluxes of natural radionuclides in the production process of a phosphoric acid plant / Bolivar J.P., Martin J.E., Garcia-Tenorio R., Perez-Moreno J.P., Mas J.L. // Appl. Radiat. Isot. - 2009. - Vol. 67. - P. 345-356.

3. The physicochemical data of extraction with the mixed solvent of NOA and MIBK from hydrochloric acid route phosphoric acid / Li W., Peng R., Ye P., Iv X., Zhu T., Cao Z., et al. // J. Chem. Thermodyn. - 2019. - Vol.131. - P.404-409.

4. Comparative analysis of industrial processes for cadmium removal from phosphoric acid: a review / Kouzbour S., Gourich B., Gros F., Vial C., Allam F., Stiriba Y. // Hydrometallurgy. 2019. - Vol.188. - P.222-247.

5. Gobbitt J.M. Yara hemihydrate (HH) and hemidihydrate (HDH) processes for phosphoric acid production // Procedia Eng. - 2012. - Vol.46. - P.143-153.

6. Technology for manufacturing fertilizer «Superfos» containing nitrogen, phosphorus, sulfur and calcium / Sadykov B.B., Volynskova N.N., Namazov S.S., Beglov B.M. // Russ. J. Appl. Chem. - 2008. - Vol.81. - P.1667-1672.

7. Production of NP fertilizers based on the decomposition of poor phosphates using a mixture of phosphoric and sulphuric acids / Rasulov A.A., Alimov U.K., Seytnazarov A.R., Namazov S.S., Sultonov B.E. // J. Chem. Technol. Metall. - 2019. - Vol.54. No. 6. - P.1263-1270.

8. Balanced NP-and NPK-fertilizers based on purified ammophos suspension, nitrogen fertilizers and potassium chloride / Nomozov S.Y., Namazov S.S., Seytnazarov A.R., Beglov B.M., Alimov U.K. // Int. J. Sci. Technol. Res. - 2020. - Vol.9. No. 2. - P.1572-1578.

9. Siminovich $C$., Joao $S$. Dynamic operator training simulators for sulphuric acid, phosphoric acid, and DAP production units // Procedia Eng. - 2014. - Vol.83. - P.215224.

Bekhzod Karshiev, Atanazar Seytnazarov, Umarbek Alimov, Shafoat Namazov, Akhmed Reymov, A'zamjon Rasulov 
10. Wet-process phosphoric acid obtained from Kola apatite. Purification from sulphates, fluorine, and metals / Kijkowska R., Pawlowska-Kozinska D., Kowalski Z., Jodko M., Wzorek Z. // Sep. Purif. Technol. - 2002. - Vol.28. - P.197-205.

11. Recovery of high grade phosphoric acid from wet process acid by solvent extraction with aliphatic alcohols / Amin M.I., Ali M.M., Kamal H.M., Youssef A.M., Akl M.A. // Hydrometallurgy. - 2010. - Vol.105. - P.115-119.

12. Purification of wet process phosphoric acid by solvent extraction with TBP and MIBK mixtures / Hannachi A., Habaili D., Chtara C., Ratel A. // Sep. Purif. Technol. - 2007. - Vol.55. P.212-216.

13. Purification of wet process phosphoric acid using organics solvents / Karshiev B., Seytnazarov A., Namazov S., Radzhabov R., Reymov A., Alimov U. // J. Crit. Rev. - 2020. Vol.7. - No. 17. - P.2913-2918.

14. Processing new concentrate from phosphorites of Central Kyzylkum, containing $26 \% \mathrm{P}_{2} \mathrm{O}_{5}$, on wet-process phosphoric acid, monoammonium phosphate and diammophos / Namazov S.S., Seytnazarov A.R., Beglov B.M., Volynskova V.N., Sadykov B.S., Myrzakulov H.C. // Chem. J. Kazakhstan. - 2014. - Vol.3. P.158-167.

15. Vinnik M.M., Erbanova L.N., Zaytsev P.M. Methods of analysis of phosphate raw material, phosphorus and complex fertilizers, feed phosphates. - M.: Khimiya, 1975. -218 p.

Received 11.11.2019

\section{ОЧИЩЕННЯ ЕКСТРАКЦИЙНОЇ ФОСФОРНОЇ КИСЛОТИ МЕТОДОМ ДЕСУЛЬФУРИЗАЦІЇ ТА АМОНІЗАЦІЇ}

\section{Б.Н. Кариієв, А.Р. Сейтназаров, У.К. Алімов, II. С. Намазов, А.М. Реймов, А.А. Расулов}

Досліджено процес десульфуризації екстракційної фосфорної кислоти, одержаної з митого відпаленого концентрату з наступним очищенням кислоти від двох і тривалентних металів та фтору шляхом часткової амонізації (при $\mathrm{pH}$ від 2 до 4). Амонізована пульпа, що містить $16,96 \% \mathrm{P}_{2} \mathrm{O}_{5}$; $8,06 \% \mathrm{~N}, 0,09 \% \mathrm{CaO}, 0,58 \% \mathrm{MgO} ; 0,004 \% \mathrm{Fe}_{2} \mathrm{O}_{3} ; 0,031 \% \mathrm{Al}_{2} \mathrm{O}_{3}$; $0,78 \% \mathrm{SO}_{3}$ i $0,52 \% \mathrm{~F}$, була одержана за допомогою видалення осадів на стадії десульфуризації і амонізації. Вивчені реологічні властивості амонізованої пульпи із вмістом $40 \%$ вологи. При зростанні температури від 40 до $80^{\circ} \mathrm{C}$ як густина, так і в'язкість знижується з 1,395 до $1, .365$ г/ $\mathrm{cm}^{3}$ і від 80,8 до 48,7 сПз, відповідно. Амонізована суспензія з рH 5,5 і 8,5 була застосована для одержання моно- і діамонійфосфатів зі співвідношенням $\mathrm{P}_{2} \mathrm{O}_{5}: \mathrm{N}$, рівним 52:14 і 48:18, відповідно. Шламові осади, отримані у процесі десульфуризації і амонізації, можуть бути використані як повільно діючі добрива.

Ключові слова: екстракційна фосфорна кислота, кальцієвмісні матеріали, десульфуризація, амонізація, шламовий осад, моно- і діамонійфосфати, склад.

\section{PURIFICATION OF WET PROCESS PHOSPHORIC ACID BY DESULFURIZATION AND AMMONIZATION}

B.N. Karshiev ${ }^{a}$, A.R. Seytnazarov ${ }^{a}$, * U.K. Alimov ${ }^{b}$, Sh.S. Namazov ${ }^{a}$, A.M. Reymov ${ }^{c}$, A.A. Rasulov ${ }^{a}$

a Institute of General and Inorganic Chemistry of Academy of Sciences of the Republic of Uzbekistan, Tashkent, Uzbekistan

b Tianjin University of Science and Technology, Tianjin, People's Republic of China

c Karakalpak State University, Nukus, Uzbekistan

*e-mail: atanazar77@mail.ru

We studied the processes of desulfurization of phosphoric acid obtained by wet process from washed and roasted concentrate and subsequent purification of acid from bivalent and trivalent metals and fluorine via partial ammonization (at $\mathrm{pH}$ of 2 to 4). Purified ammoniated slurry containing $16.96 \% \mathrm{P}_{2} \mathrm{O}_{5}, 8.06 \% \mathrm{~N}$, $0.09 \% \mathrm{CaO}, 0.58 \% \mathrm{MgO}, 0.004 \% \mathrm{Fe}_{2} \mathrm{O}_{3}, 0.031 \% \mathrm{Al}_{2} \mathrm{O}_{3}, 0.78 \%$ $\mathrm{SO}_{3}$ and $0.52 \% \mathrm{~F}$ was fabricated by the removal of precipitates at the stages of desulfurization and partial ammonization. The rheological properties of ammoniated slurry with $40 \%$ moisture were studied. When the temperature is increased from 40 to $80^{\circ} \mathrm{C}$, both the density and viscosity decrease from 1.395 to $1.365 \mathrm{~g} \mathrm{~cm}^{-3}$ and from 80.8 to $48.7 \mathrm{cP}$, respectively. Ammoniated suspension with $\mathrm{pH}$ of 5.5 and 8.5 was applied to prepare mono- and diammonium phosphates with the ratio $\mathrm{P}_{2} \mathrm{O}_{5}: \mathrm{N}$ of $52: 14$ and $48: 18$, respectively. The sludge obtained after desulfurization and ammonization processes can be used as a slow-release fertilizer.

Keywords: wet process phosphoric acid; calcium-containing material; desulfurization; ammonization; sludge; mono- and diammonium phosphates; composition.

\section{REFERENCES}

1. Babrauskas V. Phosphorus explosions. Process Saf Environ Prot. 2017; 107: 87-93. doi: 10.1016/j.psep.2017.01.026.

2. Bolivar JP, Martin JE, Garcia-Tenorio R, Perez-Moreno JP, Mas JL. Behaviour and fluxes of natural radionuclides in the production process of a phosphoric acid plant. Appl Radiat Isot. 2009; 67: 345-356. doi: 10.1016/j.apradiso.2008.10.012.

3. Li W, Peng R, Ye P, Iv X, Zhu T, Cao Z, et al. The physicochemical data of extraction with the mixed solvent of NOA and MIBK from hydrochloric acid route phosphoric acid. J Chem Thermodyn. 2019; 131: 404-409.

doi: $10.1016 /$ j.jct.2018.11.012.

4. Kouzbour S, Gourich B, Gros F, Vial C, Allam F, Stiriba Y. Comparative analysis of industrial processes for cadmium removal from phosphoric acid: a review. Hydrometallurgy. 2019; 188: 222-247. doi: 10.1016/j.hydromet.2019.06.014.

5. Gobbitt JM. Yara hemihydrate $(\mathrm{HH})$ and hemidihydrate (HDH) processes for phosphoric acid production. Procedia Eng. 2012; 46: 143-153. doi: 10.1016/j.proeng.2012.09.457.

6. Sadykov BB, Volynskova NN, Namazov SS, Beglov BM. Technology for manufacturing fertilizer «Superfos» containing nitrogen, phosphorus, sulfur and calcium. Russ J Appl Chem. 2008; 81: 1667-1672. doi: 10.1134/S1070427208090371.

7. Rasulov AA, Alimov UK, Seytnazarov AR, Namazov SS, Sultonov BE. Production of NP fertilizers based on the decomposition of poor phosphates using a mixture of phosphoric and sulphuric acids. J Chem Technol Metall. 2019; 54(6): 12631270 . 
8. Nomozov SY, Namazov SS, Seytnazarov AR, Beglov BM, Alimov UK. Balanced NP-and NPK-fertilizers based on purified ammophos suspension, nitrogen fertilizers and potassium chloride. Int J Sci Technol Res. 2020; 9(2): 1572-1578.

9. Siminovich C, Joao S. Dynamic operator training simulators for sulphuric acid, phosphoric acid, and DAP production units. Procedia Eng. 2014; 83: 215-224. doi: 10.1016/j.proeng.2014.09.041.

10. Kijkowska R, Pawlowska-Kozinska D, Kowalski Z, Jodko M, Wzorek Z. Wet-process phosphoric acid obtained from Kola apatite. Purification from sulphates, fluorine, and metals. Sep Purif Technol. 2002; 28: 197-205. doi: 10.1016/S1383-5866(02)00048-5.

11. Amin MI, Ali MM, Kamal HM, Youssef AM, Akl MA Recovery of high grade phosphoric acid from wet process acid by solvent extraction with aliphatic alcohols. Hydrometallurgy. 2010; 105: 115-119. doi: 10.1016/j.hydromet.2010.08.007.
12. Hannachi A, Habaili D, Chtara C, Ratel A. Purification of wet process phosphoric acid by solvent extraction with TBP and MIBK mixtures. Sep Purif Technol. 2007; 55: 212-216. doi: 10.1016/j.seppur.2006.12.014.

13. Karshiev B, Seytnazarov A, Namazov S, Radzhabov R, Reymov A, Alimov U. Purification of wet process phosphoric acid using organics solvents. J Crit Rev. 2020; 7(17): 2913-2918. doi: $10.31838 /$ jcr.07.17.367.

14. Namazov SS, Seytnazarov AR, Beglov BM, Volynskova VN, Sadykov BS, Myrzakulov HC. Processing new concentrate from phosphorites of Central Kyzylkum, containing $26 \% \mathrm{P}_{2} \mathrm{O}_{5}$, on wetprocess phosphoric acid, monoammonium phosphate and diammophos. Chem J Kazakhstan. 2014; 3: 158-167. (in Russian).

15. Vinnik MM, Erbanova LN, Zaytsev PM. Methods of analysis of phosphate raw material, phosphorus and complex fertilizers, feed phosphates. Moscow: Khimiya; 1975. 218 p. (in Russian). 